\title{
A Perceptual Mapping Approach to Determine an Appropriate Descriptor for our Field
}

\author{
John A.W. Baker \\ Southern Illinois University at Edwardsville \\ Ken Hardman \\ Manchester University \\ David W. Pan \\ The University of Oklahoma
}

In the United Kingdom there has been a trend since the latter part of the 1970's to develop new degrees in sport science and related fields such as recreation and leisure management. Margaret Thatcher's 'white paper' Framework for Expansion (1975) was a government policy statement 'blueprint' for the future development of teacher education. Ironically, expansion was political speak for 'rationalisation' as ultimately contraction occurred by concentration of teacher education in fewer higher learning institutions. For example, there were initially 147 institutions involved in training physical education teachers, but mergers and closures resulted in a reduction to around 20 institutions offering courses for graduate teachers with a physical education qualification.

The rationalisation process obliged many institutions to seek salvation (survival) in diversified degree and two-year Higher Education Diploma course programmes. It spawned 'new' programmes to replace (or displace) the physical education (as a major) B.Ed. degree. Consequently, degree programmes, variously termed B.A./B.Sc./ B. Hum (Humanities), were rapidly developed, in some cases cynics would argue, to enable institutions to survive. Thus, programme titles such as Human Movement Studies, Sport Science, Sports Studies, Sport and Recreation, Leisure Studies and the like began to appear and subsequently have proliferated. Some institutions retained the term physical education as a degree course in its own right, but extended the period of study to four years to include qualified teacher status, so-called Q.T.S., programmes.

During the same period as (and even prior to) the developments, and to a large extent signalling prevailing attitudinal and perhaps philosophical changes, there was widespread debate ${ }^{1}$ about terms and terminology in relation to physical education, movement and sports sciences. The debate culminated in a shift in some quarters toward degree courses bearing titles related to movement, sport, exercise, recreation and leisure studies, which would more truly represent physical activity as an academic area of study within the scientific community. Clearly, such developments suggest a trend in the United Kingdom away from the term 'physical education' - with its generic connotations and essentially pedagogical focus - to ostensibly more academic and specialist scientific oriented terms.

Up to this point, rationalisation for the use of a particular descriptor to represent what we do in our field has been limited to philosophical essays. It was of interest to these authors, therefore, to extend beyond this by providing an objective approach to determine how faculties in the United Kingdom view a series of titles in terms of their association with different attributes, and also arrive at a title which they consider best represents our field. 
This was achieved with the use of a Multidimensional Scaling (MDS) technique developed by Kruskal (1964) which is being widely used in the business sector. This method generates perceptual maps which allow researchers to assess consumer perceptions of where competing products (in this case departmental titles) are positioned in the market according to the amount of key attributes they are believed to possess. One of the several MDS computer programmes used to accomplish this was Multidimensional Preference Analysis (MDPREF).

\section{Procedures for Collecting and Analyzing Data}

MDPREF is a unique procedure that uses a grid in the data collection stage and graphic map in data presentation. The latter provides an ideal format for introducing data of respondent perceptions to a large group of people because of its visibility and ease of interpretation. The grid for this study was constructed using a vertical list of 13 departmental titles which included exercise science, exercise studies, human movement, movement science, human development, human performance, human kinetics, kinesiology, physical education, physical culture, sport and exercise science(s), sport science(s), and sport study(ies); (the term physical culture was included to accommodate an international study being conducted simultaneously). A row of attributes which described these titles to varying degrees was placed adjacent to the list. These included: 'has a professional orientation', 'has a discipline orientation', 'is prestigious in academe', 'is prestigious in society', and 'is representative of our field'. A seven point Likert-type scale ranging from 'a great amount of association' to 'no association' was used to record the degree to which respondents perceived each attribute to be associated with each title.

The grid and a letter explaining the purpose of the study were mailed to a random sample of lecturers, senior/ principal lecturers and professors in departments of physical education (or whatever term had been assumed) in universities in the United Kingdom. The population $(N=35)$ was asked to rate, according to the scale, the degree to which they perceived each attribute was associated with each title and place that number in the appropriate place on the grid. The completed $13 \times 5$ matrix thus contained 65 numbers. Demographic information regarding a respondent's area of specialization was also obtained. All 35 $(100 \%)$ surveys were returned and were usable in the study. To facilitate data analysis, respondents were segmented according to four related areas of academic specialization (motor behaviour/sport psychology; exercise physiology; social sciences; physical education/teacher education).

The mean scores of ratings for each attribute to each title were generated from the matrices. These data were analyzed using the MDPREF programme which uses a point-to-vector model to derive graphic maps showing the positions of stimuli points (the department titles) in relation to subject vectors (key attributes). The model assumes a linear form such that a respondent's preference becomes stronger as it moves an infinite distance along the vector. To form the subject vectors, the programme draws lines from the origin of a plot through the graph axis to infinity. Next, the stimuli point is projected on to each vector at an angle of 90 degrees. This projection shows a respondent's average preference of the stimuli in respect to the subject vectors (Smith, 1990). A series of maps thus were generated for each group of respondents showing the perceived importance of the 13 departmental titles relative to the five selected attributes.

\section{Results}

The results of the MDPREF analysis for each group of respondents are plotted in Figure 1 . As previously stated, the degree to which a point (title) is associated with each vector (attribute) becomes stronger as it moves along the vector.

\section{Motor Behaviour/Sport Psychology group $(N=7)$}

The titles sport science(s), sport and exercise science(s), and exercise sciences(s) were considered by this group to have a strong discipline orientation, as 
Figure 1: Maps of 13 departmental titles and their association with five attributes as perceived by respondents with different professional preparation
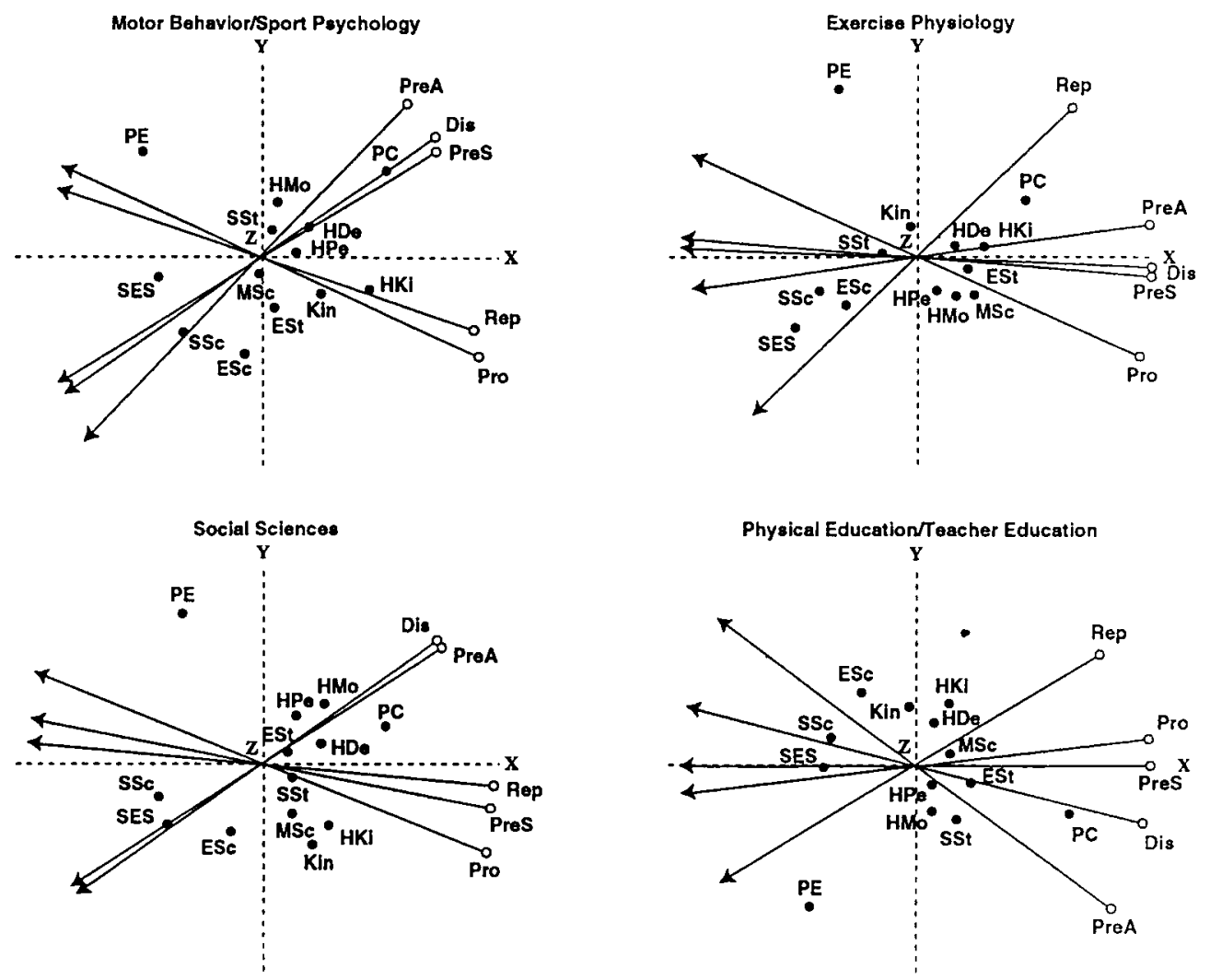

ATTRIBUTES

DEPARTMENTAL TITLES

Dis = Discipline Orlentation

Pro = Professional Orientation

Rep $=$ Representative of Our Field

Pres = Prestiglous in Society

PreA = Prestiglous in Academe

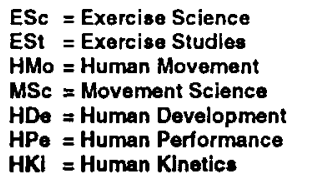

Kin = Kinesiology

$\mathrm{PE}=$ Physical Education

PC = Physical Culturo

SES = Sport and Exerciso Science (s)

$\mathrm{SSc}=$ Sport Science (s)

SSt $=$ Sport Study (ies)

HKI = Human Klnetice

well as being prestigious in both academe and in society. The title physical education was considered to have a strong professional orientation as, to a lesser degree was that of sport and exercise science. The term physical education was considered by this group to be most representative of what we do in our field.

\section{Exercise Physiology group ( $N=7$ )}

The titles sport and exercise science(s), sport science(s), and exercise science(s) were considered to have a strong discipline orientation; to be prestigious in academe and society; to have a high degree of professional orientation; and were most representative of our field. The term physical education was thought to have the strongest. professional orientation and to a lesser degree some prestige in sociéty.

\section{Social Sciences group $(\mathbf{N}=\mathbf{8})$}

The titles sport and exercise sciences (s), sport science(s), exercise science(s), and sport study(ies) were considered to have a strong discipline orientation and were thought to be prestigious in academe. To this group, physical education along with sport science(s), sport and exercise science(s), and sport study(ies) not only had the strongest professional orientation and prestige in society, but were most representative of our field. 


\section{Physical Education/Teacher Education group ( $N=13$ )}

This group considered the titles physical education, sport and exercise science(s), and sport science(s) to have a strong professional orientation, were seen as prestigious in society and most representative of our field. The terms sport science(s), sport and exercise science(s), physical education, and exercise science(s) were also thought to have a strong discipline orientation; and sport science(s), exercise science(s), and sport and exercise science(s) were considered to be prestigious in academe.

In addition to providing the graphs, the MDPREF programme also produced correlation coefficients showing the strength of the relationship among the five attributes, thus allowing the authors to assess whether respondents thought that titles representing our field should have a professional orientation, a discipline orientation, should be prestigious in academe, or prestigious in society.

A correlation matrix showing the strength of the relationships between the attributes is presented in Table 1. As can be seen, respondents in the Motor Behaviour group consider that any title representing our field should have a professional orientation $(r=.7784)$ rather than a discipline orientation $(r=.4408)$. This group also believed it was unnecessary for such a title to be prestigious in academe $(r=.3202)$ or society $(r=.3004)$. Respondents concurred that a title with a discipline orientation would be prestigious in academe $(r=.9116)$ and society $(r=.7019)$, however if it had a professional orientation it would be seen as neither prestigious in academe $(r=.1292)$ nor in society $(r=.4055)$.

Respondents in the Social Sciences group and Physical Education/Teacher Education group agree that a title representative of our field should be professionally oriented $(r=.8595$ and .8205 respectively), which would also provide prestige in society $\langle r=.9001$, .6793). Both groups also consider that such a title would have a discipline orientation ( $r=.6765, .5548)$ and the Social Sciences group believe that such a title would provide a reasonable measure of prestige in academe $(r=.6012)$. Respondents in the Physical Education/ Teacher Education group consider it unnecessary for a title representing our field to be prestigious in academe.

Respondents in the Exercise Physiology group believe that a title with a professional orientation would not be representative of our field $(r=.2533)$. They consider that a title should be seen as prestigious in academe $(r=.6346)$ and society ( $r=.5634$ ). This group, however, considers that any title prestigious in society should also have a professional orientation $(\mathrm{r}=.8909$, a discipline orientation $(r=.7717)$ and prestige in academe $(r=.8236)$. They also consider that a title prestigious in academe could have both a professional orientation $(r=.6527)$ or discipline orientation $(r=.8669)$.

\section{Discussion}

The greatest change in our field during the last 30 years has been the increasing diversity of programmatic offerings beyond certification in teacher education. Opportunities to earn undergraduate and graduate degrees in physical education have caused a re-evaluation of the restriction imposed by this title because of faculty diversity, curricula content, and the array of specializations which have emerged over and above teacher education. Descriptors perceived to reflect these different programmatic foci are displayed in the graphs.

Four of the 13 titles were perceived to have a large degree of association with the attributes used. The titles sport science(s), sport and exercise science(s), and exercise science(s) were considered to have a strong discipline orientation in addition to providing prestige in both academe and society at large. The term perceived to have the strongest professional orientation was that of physical education followed by sport and exercise science(s), sport science(s), and exercise science(s). Physical education also was perceived by respondents in the social science and physical education/teacher education groups as one which provided prestige in society. 
Table 1

Correlation matrix for the relationship between five attributes and respondents' areas of specialization

\begin{tabular}{lcccc}
\hline & $\begin{array}{c}\text { Professional } \\
\text { Orientation }\end{array}$ & $\begin{array}{c}\text { Discipline } \\
\text { Orientation }\end{array}$ & $\begin{array}{c}\text { Prestigious } \\
\text { in Academe }\end{array}$ & $\begin{array}{c}\text { Prestigious } \\
\text { in Society }\end{array}$ \\
\hline $\begin{array}{l}\text { Motor Behaviour } \\
\text { Discipline Orientation }\end{array}$ & .3428 & & & \\
Prestigious in Academe & .1292 & .9116 & & \\
Prestigious in Society & .4055 & .7019 & .5832 & .3004 \\
Representative of our Field & .7784 & .4408 & .3202 & \\
& & & & \\
Exercise Physiology & .7254 & & & \\
Discipline Orientation & .6527 & .8669 & .5634 \\
Prestigious in Academe & .8909 & .7717 & .8236 & \\
Prestigious in Society & .2533 & .4770 & .6346 & \\
Representative in our Field & & & & \\
Social Sciences & .4138 & & & \\
Discipline Orientation & .4103 & .8973 & .6001 \\
Prestigious in Academe & .9035 & .5490 & .6236 & \\
Prestigious in Society & .8595 & .6765 & .6012 & \\
Representative of our Field & & & & \\
Physical Education/Teacher Education & .8644 & & & \\
Discipline Orientation & .6170 & .8785 & & \\
Prestigious in Academe & .8046 & .7459 & .6660 & \\
Prestigious in Society & .8205 & .5548 & .2242 \\
Representative of our Field & & & & \\
\hline
\end{tabular}

The use of the word sport, exercise, or science in a title has been supported by several authors (Kretchmar, 1989; Katch, 1989; Higgins, 1989; Thomas 1987). Sport, for example, can be perceived as a generic term inferring exercise, athletics and movement. There are academic programmes of sport medicine, sport management, sport sociology, sport psychology, sport law, et cetera. Each implies an academic and stringent disciplinary preparation over and above an activity based professional programme.

The term exercise as a separate entity is vague, but along with the term science, reflects preparation in the natural, behavioural and social sciences in addition to the humanities. The titles sport and exercise science(s), sport science(s), and exercise science(s) reflect the study of humans during the physical activities of sport and exercise. These titles include the areas of motor integration, exercise physiology and biomechanics, and departments using such titles provide programmes of study that interrelate content and research based speciality areas. These terms, however, appear to be a deliberate separation of the academic discipline from traditional pedagogy and teacher education. The emphasis on 'science' in these titles is not only an attempt to describe what we do in most of our sub-speciality areas, but follows the trend of trying to portray a new image to university-wide faculty, the community-atlarge, and funding agencies. The latter appear more likely to support grant applications from programmes that emphasize the basic sciences than those which do not (Bird, 1988).

The term physical education was perceived to have the strongest professional orientation and also was seen by respondents in the motor behaviour/ sport psychology, social science, and physical education/teacher education groups as being the title which most represents what we do in our field. This was not surprising as respondents in these groups traditionally have associated physical education with pedagogical training. It also was not surprising that respondents in the exercise physiology 
group preferred the titles of sport and exercise science(s), sport science(s), or exercise science(s) as most representative of what we do as they reflect attempts to link sport, exercise, and science to a scholarly, academic approach to study and research in our area.

It was interesting to note that respondents did not perceive the term kinesiology as being associated to a large degree with any of the attributes. This label has been promoted intensely in the United States by Caldwell (1987) and Newell (1990) and endorsed by the American Academy of Kinesiology and Physical Education (AAKPE) as the best term to describe the purposes of our graduate, undergraduate, and performance programmes.

This study sought to provide an objective approach to determine how people view disciplinary titles in terms of their association with different attributes; and also arrive at a title which is perceived to best represent our field. A single term on which we all can agree may be elusive as it will have to embrace all departmental offerings and philosophies in postsecondary education as a whole. However, despite the fact that the term physical education was not regarded as having a discipline orientation, nor being prestigious in academe or society, it was considered the most representative of what we do according to the perceptions of respondents who specialize in motor behaviour, sport psychology, the social sciences, physical education and teacher education.

\section{Footnote}

1. Reported in such journals as the Physical Education Review, The Physical Education Association's (P.E.A.) British Journal of Physical Education, and The British Association of Advisors \& Lecturers in Physical Education's (B.A.A.L.P.E.) Bulletin of Physical Education.

\section{References}

Bird, P. (1988, January). College name change A rationale. Journal of Physical Education, Recreation and Dance, 59 (1), 25-27.

Caldwell, S. (1987). How can physical education improve its status in public schools? Journal of Physical Education, Recreation and Dance, 58 (6), 7.
Higgins, J. (1989, October). The naming debate: Movement science. Journal of Physical Education, Recreation and Dance, 60 (8), 66-67.

Katch, F. (1989, October). The naming debate: Exercise Science - it's more than just a name change. Journal of Physical Education, Recreation and Dance, 60 (8), 71-72.

Kretchmar, S. (1989, October). The naming debate: Exercise and Sport Science. Journal of Physical Education, Recreation and Dance, 60 (8), 68-69.

Kruskal, R. (1964). Multidimensional scaling: A numerical method. Psycometrica, 29, 115-129.

Newell, K. (1990). Kinesiology: The label for the study of physical activity in higher education. Quest, 42, 269-278.

Smith, S. (1990). PC-MDS: Multidimensional Statistics Package. Provo, UT: Institute of Business Management.

Thomas, J. (1987). Are we already in pieces, or just falling apart? Quest, 39, 114-121.

\section{Résumé}

Une démarche afin de déterminer un descripteur adéquat à notre domaine

Une technique de 'multidimensional scaling' fut utilisée pour déterminer comment les personnes ayant fourni des réponses (lecteurs et professeurs au Royaume Uni) percevaient les différents titres de leur département, en termes $d^{\prime}$ association avec des attributs choisis et afin d'arriver au titre le plus représentatif de notre domaine. D'une série de cartes perceptuelles, l'auteur constate que les titres science(s) du sport, sport et science(s) de l'exercice (pas nécessairement dans cet ordre) étaient considérés comme présentant la plus forte orientation disciplinaire et le prestige le plus élevé dans la société et les milieux académiques. Le titre éducation physique fut perçu comme celui qui possédait la plus forte orientation professionnelle. Les personnes spécialisées en physiologie de l'exercice préfèrentle terme de science de l'exercice et du sport qui représente le mieux notre domaine alors que les spécialistes du comportement moteur, de la psychologie du sport, des sciences sociales, de l'éducation physique et de la formation des enseignants préfèrent le terme éducation physique.

M. Piéron 


\section{Zusammenfassung}

Der Ansatz einer begrifflichen Auslotung zur Bestimmung einer angemessenen Bezeichnung in unserem Fachgebiet.

Eine mehrdimensionale Bewertungstechnik wurde verwendet, um herauszufinden, wie Befragte (HochschulDozenten und Professoren in England) verschiedene Bereichsbezeichnungen im Bezug auf ausgewählte Zuschreibungen bewerteten und um einen Namen zu finden, der am besten unser Fachgebiet überschreibt. Durch eine Reihe von begrifflichen Vorschlägen fand man heraus, daß die Bezeichnungen Sportwissenschaft(en), Sport- und Trainingswissenschaft(en) und Trainingswissenschaft (nicht unbedingt in dieser Reihenfolge) die stärkste Fachorientierung sowie das größte Ansehen in der Gesellschaft und in der Fachwelt aufwiesen. Die Bezeichnung 'Sportunterricht' (physical eduation) wurde von allen Befragten als die mit der stärksten beruflichen Orientierung eingeschätzt. Befragte im Spezialgebiet 'Leistungsphysiologie' bevorzugten die Begriffe 'Sport und Trainingswissenschaften' als die das Fachgebiet am besten beschreibende, im Gegensatz dazu wurde die Bezeichnung 'Sportunterricht' (physical education) von denen bevorzugt, die ihren Schwerpunkt in Bewegungslehre, Sportpsychologie, Sozialwissenschaften, Sportpädagogik und in der Lehrerbildung hatten.

G. Doll-Tepper

\section{Resumen}

La determinacion del descriptor mas apropiado para definir nuestro campo de conocimiento. Utilizacion de mapas perceptivos.

A un grupo de profesores universitarios del Reino Unido de diferente posición académica se les conminó a que manifestaran como percibian diferentes títulos departamentales con el objeto de evaluar su grado de asociación con determinados atributos, así como distinguir aquél que, en su opinión, mejor representaba nuestro campo de conocimiento. Para ello, se utilizó una técnica de Escala Multidimensional (MDS). A partir del establicimiento de una serie de mapas perceptivos se encontró que los títulos Ciencias del Deporte, Ciencias de la Actividad Física y del Deporte, y Ciencias de la actividad Física (no especialmente en este orden) fueron considerados como aquellos que tenían mayor capacidad orientativa de la disciplina, así como un mayor grado de prestigio, tanto en el ámbito social como en el académico. El título Educación Física fue valorado por parte de todos los profesores interrogados como el que mayor capacidad de orientación profesional poseía. Los profesores que estaban especializados en Fisiología del Ejercicio prefirieron el término Ciencias de la Actividad Física y del Deporte como el descriptor que en mayor medida definía nuestro campo de conocimiento. Sin embargo, los que estaban especializados en Comportamiento Motor, Psicología del Deporte, Ciencias Sociales, Educación Física y Formación del profesorado, prefirieron el desçriptor Educación Física como el más representativo.

J. Campos-Granell 